\title{
Civilisations
}

Revue internationale d'anthropologie et de sciences

humaines

$69 \mid 2020$

Public spaces in late socialist East Asia: Interactions, performativity, citizenship

\section{Public spaces in late socialist East Asia: Interactions, performativity, citizenship}

Les espaces publics en Asie orientale sous le socialisme tardif: interactions, performativité, citoyenneté

Vanessa Frangville, Pierre Petit and Lisa Richaud

\section{OpenEdition}

\section{Journals}

\section{Electronic version}

URL: https://journals.openedition.org/civilisations/6128

DOI: 10.4000/civilisations.6128

ISSN: 2032-0442

\section{Publisher}

Institut de sociologie de l'Université Libre de Bruxelles

\section{Printed version}

Date of publication: 1 December 2020

Number of pages: 11-31

ISBN: 978-2-9602017-4-1

ISSN: 0009-8140

\section{Electronic reference}

Vanessa Frangville, Pierre Petit and Lisa Richaud, "Public spaces in late socialist East Asia:

Interactions, performativity, citizenship", Civilisations [Online], 69 | 2020, Online since 01 November 2021, connection on 25 October 2022. URL: http://journals.openedition.org/civilisations/6128 ; DOI: https://doi.org/10.4000/civilisations.6128 


\title{
Public spaces in late socialist East Asia: Interactions, performativity, citizenship Introduction
}

\author{
Vanessa FRANGVILLE, Pierre PETIT \& Lisa RICHAUD \\ Université libre de Bruxelles (Belgium)
}

\section{Prologue}

Picture a small, white-brick-walled café with bossa nova playing in the background, only a stone's throw away from Shanghai's famous shopping area Nanjing Road. Two elder women enter. From their enthusiastic tone and unembarrassed, loud voices as they interact with the staff, one can tell that they might be regulars, and most likely Shanghai-born. One of them orders a takeaway coffee, and shortly after, Fei, a rural migrant in his mid-twenties and newly recruited waiter, brings her drink on a tray. Dressed in the white blouse that waiters are required to wear, Fei stands behind the counter, expecting the customer to pick up the cardboard cup. "Try and take it yourself", the woman says, alluding to the heat of the cup. Fei does not seem to get what she means, and the woman repeats her comment several times. He instead laughs nervously, as if to respond to what he seems to think was a joke he has failed to understand, and to which he is expected to react. Another employee eventually interrupts the awkward atmosphere to explain to Fei that the drink is too hot to hold in one's hand. Only a moment before the scene occurred, Fei had told one of the editors of this special issue (Lisa Richaud) about how bitter he finds his life spent commuting between a remote suburban area he dislikes and the city centre where he had hoped to find opportunities for the future. A few days later, Fei is fired by his exacting boss who deemed him too slow for the job. He manages to find a new position in another nearby café an open space on the ground floor of a high-rise building housing international companies. This time, however, he is assigned to the back kitchen, where he will not have to face a largely upper-class clientele.

As mundane as it appears, this scene condenses aspects which the contributions to this special issue have led us to regard as significant processes in relation to lived public spaces in late socialist East Asian countries, and which we have summed up in this issue's subtitle: interactions, performativity, citizenship. While analytically distinct, these three concepts do not constitute discrete experiential realms. Rather, they form a continuum, as is suggested by the articles in this collection, echoing recent ethnographies of public life in East Asia (Qian 2014a; Thireau 2021; Geertman et al. 2016). Let us therefore open this introduction with 
a clarification of how exactly we conceive of this continuum. In the vignette above, the trendy café provides one illustration of a changing urban landscape, ${ }^{1}$ a space where various social groups interact, and where physical (co)presence and modes of dwelling reveal vernacular capacities to give spatial forms to everyday routines and life pursuits. We may consider the visibility afforded by the workplace, in the story of the young migrant worker, not only serves the aspiration to embody cosmopolitan lifestyle, but also - to draw on some contributions in this issueof how riding through the streets of Ho Chi Minh City provides intimacy for young couples while conveying attachment to imaginaries of a modern urban culture (Nguyen). We may also reflect on how newly-built plazas are turned into stages of "vernacular modernity" through the pleasurable dancing routines of retired Chinese people (Oakes \& Yang). As the above vignette goes on to illustrate, however, some skill is required to navigate the public spaces of late socialist East Asia, much as elsewhere, especially as some bodies remain marked as other. Often, "interactions do take place, albeit only reinforcing preconceived stereotypes, prejudices and notions of irreconcilable differences" (Qian 2020: 90). Fei's embarrassment and clumsiness as he performs his role remind us how the "corporeality of citizenship" (Trnka, Dureau \& Park 2013: 1) can be at stake in public spaces. Governance often plays a crucial part in shaping the senses, thereby strengthening the "sensations of citizenship" (Trnka, Dureau \& Park 2013: 24) for some bodies and undermining them for others. In late socialist East Asia, such an ordering of the sensible unfolds through maintaining legal distinctions between rural and urban residents; policing the "civilised" outdoor spaces of Guangzhou through attempts to banish street vending (Flock, this issue); accommodating urban development or tourism (Oakes \& Yang; Wilcox, both this issue) and thereby promoting "models of public citizens" (Qian 2020: 89) to various degrees of success (see for example Earl; Nguyen; or Hykes \& Turner in this issue).

If much of what has just been described points to a conception of performativity as the display and making of cultural identities - that is, the discursive and corporeal communication of symbolic meanings (Qian 2014a) — we also seek to move beyond such an understanding. The idea that public spaces are inherently "animated" (Amin 2015) gives rise to performativity, which, in the words of anthropologist J. Lowell Lewis, refers to "the possible thematization of an event" (Lewis 2013: 7), the emergence of the remarkable amidst the flow of daily experience. Through fraught encounters or enjoyable collaboration, inhabiting public spaces has a "performative potential", inasmuch as it constitutes, as well as interrupts, the course of ordinary life (Lewis 2013: 7). The uneasiness of interactions between customers and café waiter Fei in the above vignette might acquire salience as yet another frustrating moment in the daily routine of this young migrant worker. For Western tourists, by contrast, drinking coffee in Shanghai or Luang Prabang (Wilcox, this issue) may well stand out as an enjoyable part of their "local" experience. This eventfulness of public spaces takes many forms, ranging "from the unmarked to the very elaborately framed", to build on

1 In Shanghai, the café as a public space has a long history linked with the city's colonial past and intellectual life (Pang 2006). 
Lewis's further elaboration on performativity (2013: 31). Reading through this special issue, we are invited to witness, for example, the embodied yet largely silent reactions to the loose, disruptive, mode of presence of an inebriated man in a Ho Chi Minh City bus (Earl). We also get to hear eloquent public speeches from young Beijing residents (Bellot) or observe public boards celebrating economic and social achievement in Lao villages (Stolz \& Petit). It may appear broad, but Lewis's definition bridges aspects from various scholarly traditions, ranging from Goffman's (1959) conception of "performance" as a modality of everyday interaction, to the anthropology of cultural performance as a distinctive frame of activity, and to Judith Bulter's (1990) conception of performativity as categories brought about through repeated practices (see Lewis 2013: 7-10, 153 note 11).

For those readers acquainted with East Asia, this may bring to mind the role of the state in shaping the performativity of public spaces, by framing "special events" (Lewis 2013) punctuating everyday life. These activities often entail the enactment of officially-promoted models of citizenship (see Stolz \& Petit, this issue, about village meetings). While we will return to state-making at greater length below, let us note that many of the vernacular practices examined by the contributors often exceed, if not disturb, prescribed forms of (late) socialist citizenships. If performativity speaks of the making of salient experiences in everyday life, the contributions highlight how both urbanites and rural residents take part in the production of the affective textures of public life - whether through selfregulation and deference (Earl), public narratives of suffering (Bellot), pleasurable leisure (Oakes \& Yang), or intimacy (Nguyen). If citizenship can be viewed as "civic practice through which people connect to others" (Rovisco \& Lunt 2019: 617), this special issue shows how public spaces provide grounds for people to perform, in interaction, forms of belonging on their own terms, in their own modes of appearance and through associations of variable intensity.

\section{The heuristic value of public spaces}

In this section we provide a brief review of some issues attendant to the concept of "public spaces", followed by some clarifications about our use of the adjective "late socialist" as distinct from "post-socialist". The remainder of the introduction then offers an overview of some of the key themes and epistemological perspectives that have emerged from this collection.

The three Asian socialist countries explored in this special issue have undergone deep yet gradual changes over the last four decades. In line with Lefebvre's (1991) argument that societies and space are mutually constitutive, and that an in-depth analysis of the transformation of space coincides with a study of social change, we have embarked on different research projects with a common focus on public spaces. ${ }^{2}$ As a working definition, this special issue approached public

2 The collective project GENEsYs (East Asian Youth: Identities and Practices in Public Spaces), hosted by the Université Libre de Bruxelles between 2016 and 2021, played a leading role in this thematic momentum. That project had a different scope, however, with an emphasis on youth and a regional extension to Thailand and Japan. Four of the contributions here (Marie Bellot, Nguyen Van Minh, 
space through its assumed accessibility to all; through the visibility of the actions, events, or situations unfolding through public spaces; and through a certain type of sociability that goes beyond the "minimal interactions" in urban traffic as described by Hannerz (1980). As geographer Kurt Iveson argues (2007: 11), those sites we commonly refer to as "public spaces" in everyday language retain relevance for empirical observation, even if publicness - the possibility to address a public, in Iveson's conception- does not automatically derive from such gathering places. We thus used that category of public space in a pragmatic way, as a heuristic lever to approach on-going changes in the societies under consideration.

The conceptual attractiveness of public spaces is largely due to features relating to exemplarity, moral order (Bayly 2020), governmentality (Oakes 2019). These may trigger frictions due to the varying conceptions of these points; public spaces act - always dependent on context - as magnets in social life and foster specific interactions between those engaged in them, including people who often do not know each other but behave according to shared patterns. Public spaces are privileged places of performance, whether ludic, artistic, or political (or all of these at once) and induce a sense of being on-stage rather than in the backstage of privacy or places of transit. They embody the centrality of a place and are hence perfect sites for assertive statements ranging from major political announcements to selfies devoted to substantiating claims of "being there", or "having been there", that are shared on social networks.

By their centrality, their presumptive openness, the blatancy of what is going on or displayed, the overtness of performances, the audibility of conversations and utterances, the coexistence of their use for political and ludic purposes, public spaces cumulate qualities that make them accessible to empirical observation and theoretically suggestive.

Notwithstanding the appeal of the notion, public space has seldom been a central concern in seminal works on the public sphere or on spatiality. ${ }^{3}$ Henri Lefebvre (1991) never uses the notion of public space in The production of space - perhaps as a consequence of the author's rejection of the inclination to analyse and define subcategories that would put at stake the integrated appraisal of space that he favoured. In Exploring the city (1980), Ulf Hannerz outlined the basic tenets of urban anthropology but strangely enough, never discussed the concept of public space. The very notion of Öffentlichkeit ("public sphere" or "publicness") at the heart of Habermas' theories on social debate and political deliberation (1978 [1962]) did not elicit a deep concern for the spatiality of such dialogues. ${ }^{4}$ Recent theoretical

Rosalie Stolz \& Pierre Petit, Phill Wilcox) were presented during the final conference of GENEsYs in May 2021 and discussed by Catherine Earl. More information on GENESyS is available on <https:// genesys.ulb.be/>; on the YouTube channel "ARC GENEsYs - Asian Youth in Public Spaces". A photo exhibition including visual material from contributors Marie Bellot, Van Minh Nguyen, Pierre Petit and Lisa Richaud is accessible on the website <https://genesys.ulb.be/exhibition-asian-youth-in-publicspaces $>$.

3 With its interest in how the privatisation of public space threatens the existence of a democratic public sphere, the work of Don Mitchell (1995) counts as a notable exception here.

4 Öffentlichkeit has been translated by "espace public" (public space) in French, but this is an overinterpretation. The English translation as "public sphere", which refers more to communication than 
shifts are nonetheless worth mentioning. Kurt Iveson (2007), for example, has emphasised the importance of reintegrating "the particular materiality of different forms of space" (p. 11) in what he refers to as a "procedural" (i.e., Habermasinspired) approach to public space, with a focus on collective action and debate. Often overlooked in this line of thinking, Iveson argues, is "the persistent power of normative topographical mappings" (2007: 14). More recently, Judith Butler's writings on public assemblies have called for a better conceptualisation of spatiality, not only as a condition for, but also as an outcome of, political action. If public space is infrastructural to the very possibility of gathering, Butler (2015: 71) points out that political theorists such as Hannah Arendt have often failed to recognise how "assembly and speech reconfigure the materiality of public space and produce, or reproduce, the public character of that material environment".

Despite the attractiveness of the notion and the presumption that it should be easy to define on empirical grounds, public space constitutes a conceptual jellyfish. At least three issues reveal significant gaps in the use of the concept.

First, public space is a notion that has only been applied to urban settings. This relates to the specific imaginaries that tend to associate public spaces - streets, squares and parks, cafés and bars, and the like- with metropolitan life. Relatedly, restrictive uses of the concept to urban contexts might be viewed as the outcome of what Iveson (2007) referred to as a "sociological approach" in which the public realm was mainly defined as the locus of stranger interactions (see Lofland 1973, 1998 or Goffman 1963). Contesting such views, the contribution by Rosalie Stolz and Pierre Petit evaluates the heuristic potential of the concept based on their ethnographic experience in two highland villages of Laos. This is an important observation, for it questions the implicit bases of the concept and enlarges the debate to incorporate places and societies that have never been approached in this field of analysis.

A second concern is the difficulty in differentiating public spaces from other categories of space, notably from private spaces. Indeed, from feminist critique (Gal 2002) to urban ethnographies (Iveson 2007; Lofland 1998), scholars have drawn on various theoretical perspectives to nuance the private/public dichotomy, including in the West where the distinction was initially conceptualised. This porosity takes specific forms in East Asia, where domestic spaces overlap with external spaces (inside out), and conversely domestic spaces are opened to the outside gaze, if not to state agents (outside in) (see the contributions of Nguyen Van Minh, Catherine Earl, and Marie Bellot in this issue; see also Drummond 2000; Farquhar \& Zhang 2012: 57; Kim 2015). Moreover, these spaces are marked by a history that has affected their nature, which itself is shaped and altered through different temporalities: political temporalities —as state congresses or public celebration days (Richaud 2016) may take place- as well as casual temporalities such as the time of the day, days of the week, or seasons. Accelerated film images of the occupation of a public space throughout a day are useful indicators of the

to physical space, should be preferred (Lits 2014). The contribution by Marie Bellot in this issue shows, however, that addressing the two dimensions in a same movement is profitable. 
significance of this temporality that is often overlooked in research. ${ }^{5}$ This implies that any tentative list of public spaces cannot be restrictive, as the publicness of a space is never settled, whether in terms of the nature of unfolding social relations (Lofland 1998), or of the activity that happens there (Qian 2020). To draw on some of the contributors' material, spaces of intimacy and privacy may paradoxically emerge in public spaces where anonymity is permitted, such as streets and roads, as Nguyen shows. Conversely, the privacy of residential buildings housing "youth spaces", in Marie Bellot's article, enables lively public debate while avoiding excessive exposure. As Iveson rightly notes (2007: 17), "[p]ublics (as collectives) and public action are not contained within spaces typically mapped as 'public' in a topographical sense". In this special issue, we were thus eager to discuss locales one would not usually expect to find in a study dedicated to public spaces, such as rural communal places, young adults' discussion rooms, buses, motorcycles or village workhouses.

A third critical reflection concerns the actual inclusivity of public spaces. As is well known, democracy in ancient Athens was a system of government for "the people", yet women, youth, foreigners, and slaves — in fact, most of the population - were barred from the agora. Reflecting on contemporary forms of democracy, Nancy Fraser (1990) and other feminist scholars have formulated powerful critiques of the Habermassian public sphere, which they deem to overlook common forms of exclusion based on gender and class. Limited inclusion may take diverse forms, beyond issues of mere access. Geographer Qian Junxi (2020: 78), for example, has recently emphasised that this "undesirable" restriction of presence seldom unfolds through "blatant displacement of people with 'inferior' status". Public space, Qian argues, is thus better understood as a liminal zone between inclusion and exclusion. ${ }^{6}$ Similarly, Sara Ahmed (2000) has shown how our common conception of urban public spaces as the realm of stranger interactions obscures the relations of power unfolding through the co-presence of various groups of people. Such power relations may not necessarily manifest through overt "exclusion", and yet they may generate differentiated affective experiences for those appearing in public spaces. Taking examples from multicultural Western cities, Ahmed shows how the very figure of "the stranger" dear to sociologists such as Goffman and Lofland, actually conceals the fact that being in public can prove more painful for some bodies, including migrant, queer, and other non-normative subjects. To understand the "stranger" of "stranger interactions" as simply "anybody", therefore, is to lose sight of these dynamics. In East Asia, state-shaped "regimes of appearance" (Butler 2015; see Florence 2019 for a Chinese case) equally weigh upon everyday presence in public spaces, as Li Zhang (2001) has shown in her classic ethnography of rural migrants in Beijing, or as the opening vignette of a café in this introduction suggested. For marginalised groups of the population, being entitled to enter urban

5 See the video "Territorialization" produced by the Hanoi Youth Public Space project <http://www. hanoiyouthpublicspace.com/gallery/>; and McNally 2003.

6 Qian (2020: 79) argues further that "inclusion" may not necessarily generate publicness, associated as it is with "normative straitjackets". For him, there are rather "relations of co-constitution and co-evolution between inclusion and exclusion". 
public spaces does not necessarily suppress the experience of appearing to others as bodies that have been marked as negative ("uncivilised", or "lacking in quality") through politics of representations. What, for example, do rural migrants feel as they walk through the "civilised" streets of Guangzhou or engage in commercial activities (Flock)? What would the experiences be of members of ethnic groups, if they were to gather alongside plaza dancers (Oakes \& Yang)?

The articles in this special issue reflect these concerns. As highly "civilised" spaces - or rather, places projected as such by the local authorities and some segments of the population — public spaces are often "cleaned" to remove the disturbing presence of informal workers, like street vendors, as argued by Ryanne Flock in her discussion about Guangzhou, and by Madeleine Hykes and Sarah Turner in their paper on Hanoi. The village communal halls described by Rosalie Stolz and Pierre Petit in upland Laos are practically limited to a male attendance, despite public assertions of gender equality. The contribution by Phill Wilcox clearly captures the logics of inclusive and exclusive dimensions of public spaces. She describes the coffee houses in Luang Prabang as hybrid spaces that value European heritage over Lao features. While coffee as a product is indigenised and narrated as a "traditional" local product (even though it was imported by French colonisers), the practice of drinking coffee in fancy, Europeanised coffee houses excludes local consumers and is mainly favoured by foreign tourists. The unfamiliarity of the items on the menu, the foreignness of consumption practices and the configuration of the space (which is in a traditional building of the historic centre deserted by the local population) make these places barely accessible to Lao people. Wilcox thus convincingly shows the process through which some public spaces become unreachable and disconnected from any local sense of belonging.

The unequal access to public spaces is also blatant in Nguyen Van Minh's "motorbike ethnography" of Ho Chi Minh City. In Vietnam, urban dwellers are being encouraged to abandon the more "traditional" bicycles and to adopt "modern" means of mobility, such as cars. Motorcycles, however, remain extremely common in public spaces. Mobility, as stated by Nguyen, intersects with the social fabric of the city, as "one's place in the traffic reflects one's place in society", and as riding a motorcycle seems to be widely accepted as a component of "Vietnamese-ness". Yet although riding a motorcycle somewhat unexpectedly plays an important part in creating sites of intimacy and privacy within the public space (as one can display affection while cruising the city streets), gender norms remain largely reproduced, with men driving, and women sitting on the back. In this sense, moto-mobility is both a tool of differentiation (between generations, genders, classes or ethnic identities) and an opportunity for invisibility and anonymity.

At the same time, the political sensitivity of some activities held in public spaces, as Marie Bellot describes, calls for individual and collective strategies to escape from censorship and state-surveillance. Public spaces, as highly regulated spaces, not only exclude "uncivilised" people or "inappropriate" behaviours, but also preclude some debates and discourses that may be politically charged or have the potential challenge the state authority. Young people in Chinese urban centres thus need to navigate between discreet militancy and state-organised institutions, 
and also develop narrative tactics to express social discontent and criticism, or simply to address issues of public concerns (domestic violence, gender unbalance, etc.). The capacity to operate such activities in public spaces is first and foremost the privilege of a young, educated elite, as Bellot explains.

In short, the aforementioned contributions demonstrate that the public quality of so-called public spaces is more a statement than a lived reality. Under the cover of openness, inclusiveness, non-discrimination and accessibility, public space may act as a sharp line of demarcation. This variance is a source of frustration for those left behind, as demonstrated by Madeleine Hykes and Sarah Turner in their contribution on Hanoi youths.

The reservations developed in this whole section should not be taken as sufficient reason to reject the concept of public space altogether - a point we return to at greater length in our conclusion. We argue that the concept is highly relevant for understanding everyday experiences of late socialism in East Asia, if late socialism is to be taken as a synonymous for the changes within continuity that have occurred in the realm of governmentality - and consequently, of social interactions, leisure, and the presentation of self. Conversely, the collection shows how the scholarship on public spaces can benefit from ethnographic research in late socialist contexts. It is to this latter category that we now wish to turn.

\section{Late socialism in East Asia}

Though our topic is relevant worldwide, the present issue focuses on three countries of socialist East Asia: the People's Republic of China, the Socialist Republic of Vietnam and the Lao People's Democratic Republic. Scholars working on public spaces in this region often limit their research to one specific country or area (Gaubatz 2019; Gibert 2014; Kim 2015; Qian 2018; Kurfürst 2012; see McGee 2009 for an exception). The regional coverage of this special issue provides in our view a sound basis for engaging relevant comparisons, and an original crosscutting perspective on societies that share many similarities. We decided not to include the Democratic People's Republic of Korea, both due to the lack of ethnographic research in that country and to the specificity of its dictatorial regime which does not fall under the label of "late socialism" applied to the three countries under discussion.

While this special issue uses "late socialism" as the common denominator between the different countries under scrutiny, we should hasten to acknowledge the complex debates over appropriate qualifications of the historical and socio-political experiences of populations in this part of the world. Due to the many "ambiguities, contradictions, and uncertain trajectories of development" (Litzinger 2002: 33), recent years have seen a profusion of categories, among which "post-socialism" stands out as dominant in the academic terminology. Why, then, favour "late socialism"? Before we go on to offer an overview of these discussions and justify our choice, let us provide a brief sketch of some of the convergent socio-political changes and continuities in the countries under consideration, and how these processes have shaped the everyday experiences of public spaces. 
China, Vietnam, and Laos have undergone long periods of war leading to a political takeover. The authoritarian regimes installed after their revolutions have subsisted until the present day. After a period of enforced revolutionary policies, involving political purges, international closures, forms of collectivisation and bans on private activities, the three countries opened from the 1980s onward to forms of market economy and tourism. They opened partially to global flows and engaged on the road to "development" — with China first, Vietnam second, and Laos third in this respect. The three countries share a Marxist-Leninist official ideology, a centralised system of institutions devoted to social and political control, like mass organisations, Party cells at all levels of society, and police intelligence agency, as well as a strict supervision on what is expressed in public spaces, which are still a privileged setting for state propaganda. The political continuities since the early days of the regimes are obvious, perhaps more even in present times than in the last decades, when analysts observed liminal relaxations from political authoritarianism. Indeed, the authoritarian turn visible since Xi Jinping's rise in power has impacted the whole area, even in non-socialist countries.

Yet while political continuities may be strong —objectively, and even more so in state rhetoric - and are reinforced by the diplomatic alliance of this ideological block, the three countries have experienced a plethora of social evolutions since the turn of the millennium, notably in relation to public space. As the revolutionary socialist project was altered by the emergence of state-controlled capitalism and a consumer society gradually emerged, practices and imaginaries around public spaces have been deeply impacted. Motorised mobility, for instance, has become accessible to most citizens and has dramatically changed traffic practices (as discussed by Nguyen Van Minh and Catherine Earl in their cross-cutting contributions about Ho Chi Minh City); the development of real-estate projects transformed deeply the urban fabric (see Madeleine Hykes \& Sarah Turner); new forms of consumption by emerging middle-classes and increasingly autonomous youths triggered the creation of new spaces to adapt to new expectations (see Marie Bellot; Thomas \& Drummond 2003); processes of patrimonialisation have created new symbolic maps (Berliner 2010; Wilcox 2021; Salemink 2021); hybrid publics have emerged through migrations as well as domestic and international tourism (see Phill Wilcox); political and police scrutiny are supported by neighbourhood committees (Tomba 2015) and increasingly by new surveillance technologies (as briefly mentioned by Flock); while the Internet has created a virtual space that duplicates and influences interactions in and usages of physical spaces. If the stability of space is a condition for the collective memory of a society and for providing a reassuring sense of continuity, as argued by Halbwachs (1997 [1950]: 193-236), it seems safe to claim that rapid spatial change might have contributed to the deep "anxieties" (Tran 2017; Zhang 2020; Zheng 2012; Yang 2017) which characterise much of the everyday experience in the societies under consideration. ${ }^{7}$

7 On the struggles of ordinary Chinese citizens engaged in the preservation of the built environment in contexts of urban redevelopment plans, see, for example, Graezer-Bideau 2018 or Thireau 2020. For an ethnography of the affective burden of living through the unmaking of a place, see Richaud and Amin 2020 on a migrant neighbourhood in Shanghai. 
In the scholarship devoted to China, Vietnam and Laos, attempts at periodisation and conceptualisation have been rendered all the more complex by these forms of continuity entangled with sometimes rather brutal change (Schwenkel \& Leshkowich 2012). Among the different concepts in use, and despite various critiques (Müller 2019), use of the term "post-socialism" has proven rather persistent in the attempt to make sense of the combination of market logics and state-shaped practices associated with neoliberalism on the one hand, and the legacies of a revolutionary past on the other. In relation to China, Ralph Litzinger (2002) traces the emergence of post-socialism to a historical moment in the decades that followed the end of Maoism, when Chinese intellectuals articulated different critiques regarding the very nature of Chinese socialism. In China scholarship, "post-socialism" initially came to refer to this "theoretical project to reconceptualise the meanings of Chinese socialism in the context of global capitalist modernity" (Litzinger 2002: 34), yet simultaneously calling into question the legitimacy of capitalism (Zhang Xudong, cited in Huang 2020: 15; see also Litzinger 2002). Marketisation, however, has increasingly led scholars to equate post-socialism with global capitalism (see Huang 2020: 15-16).

One reason behind the reluctance of some scholars to the use of "post-socialism" lies in what the concept implies for the status of the socialist past. Beyond East Asian studies, some have emphasised how the category tends to equate socialism with a "vanishing object" (Müller 2019). This connotation explains Li Zhang's (2001: 208) favouring "late socialism" over "post-socialism" in her study of postMaoist socio-spatial reconfigurations as illustrated by the case of a migrant village in Beijing. Registering the important shifts that occurred in China after the end of the Cultural Revolution, by using "late socialism" Zhang also seeks to convey her intention "to resist the assumption that current societal transformations in China will necessarily lead to the demise of the socialist regime". Writing at a time when the post-Maoist transformations of the People's Republic had generated enthusiasm and hope for democratisation among Western commentators, Li Zhang has argued: “'Late' conveys less a sense of breakdown, rupture, and death of the existing system, than a condition characterised by some fundamentally new developments mixed with the legacy of the old system". This phase of transformation, Zhang goes on to emphasise, is critical to the emergence of "alternative societal forms" (ibid.). Late socialism, then, renders the peculiar "interplay of market forces, traditional social relations, and state regulatory power" (ibid.), as reflected in the migrant enclave where she conducted fieldwork.

There remains, however, little distinction between Zhang's understanding of "late socialism" and recent conceptions of "post-socialism" which have moved beyond the term's early associations with ending and rupture. Conducting urban ethnography in Vietnam, Christina Schwenkel (2013) makes it clear that postsocialism involves, for her, not only the lingering of the socialist past in the present, but also the very capacity of the former to intermingle with and shape the latter. Cultural studies scholar Erin Huang (2020) has recently proposed "neoliberal post-socialism" to foreground the interrelations of socialism and capitalism as they unfold within and beyond the Sinophone world. In this neoliberal post-socialist 
present, Huang (2020: 20) argues, socialism is "an infinitely reimagined past".

The plurality of expressions in use reflects the difficulty posed by the peculiar relationship between China, Laos or Vietnam and their socialist legacy - distanced at times, explicitly endorsed at others. Our own preference for "late socialism" aligns with a body of work that views this concept as more apt to foreground the "renewal rather than the death of socialism" (Bayly 2020: 2 n.1). Twenty years after the publication of Li Zhang's book, as the Chinese Communist Party has just celebrated its hundredth birthday, the use of "late" rather than "post-" socialism can no longer simply index confidence in the self-sustainability of the regime. However vague, "socialism" retains its importance as a signifier for our interlocutors in the countries covered by this special issue when describing the contemporary context. While sympathetic to the idea that grand concepts do not in themselves describe our interlocutors' lived experiences (Stewart 2007: 1), we nonetheless believe that "socialism" retains a performative force in emic language. Post-soviet scholars have sometimes argued that "[s]ocialism is no longer the prime reference point for people in Eastern Europe and the former Soviet Union, but rather one among many, including neoliberalism, nationalism, consumption, Europeanisation and globalisation" (Müller 2019: 539). By contrast, those who have conducted fieldwork in the three countries under consideration know that, despite the pluralisation of ideological frameworks, "socialism" - however adjectivised - remains the only umbrella term in Party language which the regime uses to designate itself. Socialism has thus proven rather persistent as a reference point in both official discourses and casual conversations. If few people outside of Party bureaucrats might explicitly identify as socialist subjects, the functioning of the state nonetheless remains described as socialism, in opposition to "capitalist" societies. Capitalism or neoliberalism can hardly be used to designate China, Vietnam or Laos in public contexts: academic colleagues in the three countries often have a hard time finding ways around the official terminology. According to official lines, socialism and/or communism still lie ahead in the future: they are an achievement to aim towards, not a past stage of national history (High \& Petit 2013: 8).

\section{State-making and local agency}

Public spaces offer a fertile terrain for observing how socialism performs its renewal, beyond the discursive, through the senses, in direct conjunction with capitalist consumerism (Bayly 2020: 25; Dai 1999). Beyond state operations, a lingering habitus inherited from the past is expressed through the bodily performances of ordinary citizens in public spaces (Oakes \& Yang in this issue; see also Farquhar 2009; Farquhar \& Zhang 2012; Kendall 2019: 149). Müller (2019: 545), writing in relation to Eastern Europe and Russia, has argued that to stop foregrounding the socialist past in scholarly analysis, "does not mean the end of difference, but that the difference we see is no longer owing to a socialist past". In China, Vietnam and Laos, instead, difference still owes much to the pre-reform period, as many of the articles go on to show. 
Public space appears in many contributions as closely related to practices of statemaking, that is, performances, materialisations and other enactments that make the state something more than the abstraction it actually is (High \& Petit 2013). This is not surprising considering the physical, visual, symbolic and memoryrelated features of public spaces. Obviously, the latter are a privileged - maybe the privileged - setting for state propaganda. A wide range of issues remain to be explored here, such as the strategies used to attract and retain attention in public spaces through visual and sonic mediums (see Bayly 2020 for important insights in this respect).

This special issue seeks to highlight the diverse modes of political agency in public spaces. In her contribution, Ryanne Flock shows how the Chinese concept of "civilisation" (wenming) is used performatively to shape a moral order, notably through propaganda posters displayed in the city of Guangzhou, but also through prohibitions of "improper behaviours", and "dirt, chaos and deficiencies". Public space, as she says, appears here as a "space of education". Being "civilised" is both a path to building a "modern" nation and also a condition for belonging to it. In the case of Guangzhou, Flock reminds us that urban public spaces have long been embedded in the recent state's civilising project of producing modern citizens. Regulations in line with "civilising campaigns" continuously reassess who belongs and who doesn't belong to urban public spaces, especially during national inspections - and target anyone creating "disorder", in particular street vendors and hawkers. The latter constantly negotiate their presence in public spaces, adopting strategies to avoid policemen and urban patrols.

Political agency is also apparent, although in a more indirect and subtle way, in the text of Tim Oakes and Yang Yang, as they discuss urbanistic projects that aim at redesigning city squares in Guizhou and branding them as "ethnic cultural spaces", as part of a state-supported movement of folklorisation and touristification of ethnic societies. Similarly, in Vietnam, city-dwellers are urged to conform to state-defined "civilised" forms of mobility and to "clean off" streets to make them more "cultured", as noted in the contributions of Nguyen, and Hykes and Turner. Stolz and Petit also demonstrate that the recent transformations of rural public space in Laos -including the issue of village achievement boards, the building of communal halls, the introduction of a state-controlled sonic system and the promotion of land use plans - are all instrumental in embedding villages into the state system, now even more than in a not-so-distant past.

Such assertive transformations of public space by state authorities confirm their willingness to enforce control through social engineering. In addition, as noted by Earl and Flock in the case of Vietnam and China, means of surveillance of public spaces in the city are increasingly diverse, including local patrols (like Guangzhou's chengguan), private security guards but also surveillance technology. Nguyen, on the other hand, highlights forms of governance through strict management of means and patterns of mobility, or "govermobility". But, as also shown by the contributions, this does not totally deter the population from using public spaces in ways that depart from the official political lines and predictions. 
Public spaces are also spaces to gather and protest, as we are reminded by the Tian'anmen demonstrations in Beijing in 1989 (Wu 2005). A recurring question of the articles is: what are the modes of adherence, resistance, circumvention or indifference in this new context, and how are these modes shaped through physical space itself?

The article by Tim Oakes and Yang Yang about the "plaza dance craze" in Guizhou describes a situation of divergence. As noted above, the authorities are attempting to brand provincial cities as "traditional" and "ethnic", while the local population has adopted local views on modernity and do not wish to see ethnic and exotic references in their living environment. Yet the public's reaction is not exactly confrontational. The "vernacular urban modernity" they express in plaza dancing is different from the expectations of the rising middle-class, and they are more a local reformulation of the state's project than a challenge to it. $^{8}$

Madeleine Hykes and Sarah Turner, on the other hand, discuss the reaction of Hanoi's youth to urban policies. Although these policies (especially those concerning public transport, motorbike traffic and building projects) generate concerns and frustrations, the latter are never expressed on a political level during interviews. Rather, the youth navigate the situation, "re-purposing the built environment to fit their immediate needs", grumbling against specific projects rather than policies, and envisioning a boycott of a Chinese-funded metro-project. Once again, downplaying (domestic) politics seems mandatory in any expression of dissent. ${ }^{\text {? }}$

\section{An interactional approach}

The authoritarian context of the three countries under discussion makes the issue of state-making, and the related questions of the reception of/resistance to the political agenda, all too obvious. However, if public spaces encompass important political issues, the latter should not become a straitjacket to analysis. Over the past years, the success of concepts such as resistance or everyday politics has too often led social scientists to analyse a wide range of behaviours - from informal economic activities to chorale performances via youth culture- as an expression of agency by the oppressed, the repressed, and the subaltern, in a multicultural environment. The question is therefore to what extent can we look at users' activities in public spaces through the lens of politics, when playfulness, sensorial and emotional experiences prevail in the analysis (Farquhar 2009; Qian 2014b; Richaud 2020, 2021)?

8 Using public spaces for unanticipated reformulations of state rhetoric is very common in the Lao rural context, whether for celebrating Christmas or an invented New Year festival (Petit 2012, 2013).

9 In a similar way, Geertman et al. 2016 describe how skateboarders and traceurs in Hanoi have developed "non-confrontational tactics to secure space". But despite their apparent innocuousness, such leisure practices "can be read as subversive socio-political acts", according to the authors (2016: 609). 
This special issue departs from the tendency to equate the eventfulness of public spaces with resistance and infrapolitics. Such an interpretive framework, we contend, often leaves unexplored the minutiae of social interactions as they unfold between a variety of social actors. While Hannerz (1980) has long highlighted the benefits of a Goffmanian-inspired, interactionist approach to urban spaces in his seminal work on the city, these epistemological claims have remained relatively marginalised in the anthropology of (late) socialist East Asia. How can one qualify everyday engagements with familiar strangers which are seemingly characterised by openness, and yet remain imbued with privacy and anonymity (Qian 2014a; Richaud 2018)?

The contribution by Catherine Earl exemplifies how the conceptual toolbox created by Goffman remains useful to address everyday interactions in public spaces of socialist East Asia - in this instance, in Ho Chi Minh City. Earl encourages us to see Vietnamese streets and buses as self-regulatory spaces in which social distancing (before and during the pandemic), politeness and expression of courtesy constitute norms of common-sense guiding city-dwellers in the fluxes of the city. In a vivid ethnographic vignette, she illustrates how the presence of an inebriated person in a bus mobilises the passengers' different senses, including olfaction, and triggers a shift in the matrix of social interactions. The social transcript for navigating such situations is deeply embodied, as evidenced by the reaction in unison of the coriders to the sudden occurrence of the "crisis".

In their contribution about two highland minority villages in Laos, Rosalie Stolz and Pierre Petit highlight the contrasted forms of interaction triggered by different public spaces. They observe the emergence of state-initiated, or state-controlled, public spaces that contrast with what they call the "vernacular" public spaces. The latter, which have characterised Lao villages since the distant past, are exemplified by the workhouses of the Khmu villages. These can be described as open spaces - in the multiple senses of the term - where hierarchies, kinship, gender and belonging are less compelling by comparison with other contexts. This engenders rather casual patterns of interaction. By comparison, the communal hall, with its closed walls, its rectangular shape dividing the orators from the audience, and its various visual displays of the power of the state, is the perfect place to trigger hierarchic interactions predicated by a relation to the Lao nation-state.

Together with other articles in this issue, ${ }^{10}$ these two contributions vividly demonstrate how an interactionist perspective, with its attention to moment-tomoment change in moods and atmospheres, captures public spaces in the making.

10 See, for example, Bellot's use of the Goffmanian concepts of “primary framework" and "keying”. Relying on these theoretical tools, Bellot describes and analyses singular instances of public discussions rather than seeking to recreate typical interactions as they would usually occur at the "youth space". 


\section{Intimacy, emotions and affects}

Among the similarities shared by the three countries under scrutiny, one that easily comes to mind when thinking about public spaces is what we might refer to as the "sensual life of the state", to borrow Uli Linke's term (2006). Far from being the result of discourses and "semiotic conceptual operation" (2006: 207) alone, this life of the state morphs out of "perception and experience" (2006: 208). The visual display of images and slogans (Flock, this issue; see also Bayly 2020 on Vietnam and Strobbel 2017 on Laos) continues to greet the novice eye as a hallmark of the late socialist city. And if the blaring loudspeaker has often been associated with Cultural Revolution culture in Maoist China (Li 2019), the use of sound remains salient in rural areas of the three countries (Petit \& Stolz, this issue). The promotion of "civilisation" referenced earlier, also comes with its own sensoriality: it has reshaped the spatiality and visual environment of cafés in Ho Chi Minh City (Harms 2009); in China, the visuality of newly built landscapes or iconographic propaganda comes with the regulation of smell and sound. Public spaces, from this perspective, serve as important "contact zones" between the state and the citizens, a ground for "the political productions of national affect" (Linke 2006: 207).

It remains to be seen, however, to what extent the lingering modes of socialist mass publicity manage to generate affective publics, understood through their willingness to sustain attention toward these forms of communication (Warner 2002: 60) and, for that matter, emotional involvement with them (Bayly 2020). Moreover, besides this sensual presence of the state, multiple actors are now able to intervene in the production of the affectivity of public spaces, in ways that largely exceed the expression and performance of patriotic feelings or political loyalty. The sensual and intimate experience of motorbike mobility evoked by Nguyen Van Minh in this issue, or the display of intimacy by young couples in a public park of Hanoi described by Charton and Boudreau (2017), are blatant examples that affects in public spaces are not directly predicated on state policies. In contrast, the dance craze examined by Oakes and Yang may seem reminiscent of aforementioned figures of positive-looking, smiling and warm-hearted citizens conveying national pride. But if such playful and joyful experiences of togetherness can be seen as an act of reclaiming, as Oakes and Yang argue, this is also perhaps a reclaiming of the affectivity of public experience altogether. These modes of engaging with the city might be lived on non-representational terms. Far removed from official narratives of modernity, these embodied pleasures enact the desirable feel of the city for ordinary urbanites. A focus on the affective suggests that there is still room, to a certain extent, for "different modes of being a citizen" (Rovisco \& Lunt 2019: 616).

Civil modes of copresence, as such, do not merely echo state-promoted "civilised" norms but have an affectivity in their own right. Catherine Earl's contribution illustrates this idea, albeit in slightly different ways. Attuned to the acts of "camaraderie-deference" and politeness among bus riders, Earl describes the "warm" atmospheres of self-regulated public spaces in Ho Chi Minh City. These 
spontaneous modes of "shar[ing] something personal and intimate" with strangers resonate with what Susan Bayly (2020: 11), in a recent study on political images in urban late socialist Vietnam, describes as the "capacity to feel with and for others, which is the basis of moral awareness".

It would be wrong, of course, to conceive of the affective realm as it unfolds at the grassroots as entirely autonomous from operations of governmentality. Indeed, recent scholarship has emphasised attempts at governing public expression of affects in East Asia, especially negative ones (Yang 2014, 2016). As a potential source of social unrest, negative emotions yield concerns among the authorities who have made a great deal of effort to promote positivity (Yang 2015). In this issue, however, Marie Bellot's contribution points to another line of inquiry. In the specific context of "youth spaces" in Beijing, the emotional expression of suffering does not convey political sensitivity. Strategies of co-optation of individual or private initiatives by state authorities leave little space to escape from regulations and surveillance. As a result, in order to address publicly sensitive issues like gender-based violence, the meeting organisers downplay the political dimension of the event by eliciting biographical testimonies and situate the narrative on personal and emotional levels, rather than a political one. Such strategies hence protect not only the orators (some of whom are activists), but also the audience, from accusations of political opposition: framing such events in emotional terms is precisely what allows them to remain outside of the state's purview. ${ }^{11}$ In a context where agonistic politics often remains unthinkable, Marie Bellot's article shows how spatiality can afford different modes of political agency. As such, if the outcomes of these discussions cannot be viewed as direct interventions in politics, the absence of exposure, Bellot argues, allows for the cultivation of forms of "the juxtapolitical", in Lauren Berlant's (2008) terminology.

\section{Concluding thoughts}

Vigneswaran, Iveson and Low have recently argued that in the aftermath of "dramatic events" such as the Occupy movement or the Arab spring, "public space has been reinstated as the symbolic core of urban life" (2017: 496). While this is certainly true, the contributions show that the centrality of public spaces to and beyond urban life is not only contingent upon massive critical events. Instead, this collection shows how public spaces matter to everyday life in late socialist countries through their ordinary eventfulness. As such, the articles here reassert the lingering relevance of the concept due to its heuristic value: unsettled as this concept of public space may be, it triggers creative questions on space, communication, boundaries, hierarchies, and interactions. This is certainly not a "definite" concept, but an invitation to reflection. Taken reflexively, it acts as a bridge connecting situations that would not have been approached in usual comparative perspectives, such as a protest on a city square, silent passengers riding together in a bus, a coffee break in a touristic restaurant, and an animated discussion in a village workhouse or in a

11 For a similar argument, see Christina Schwenkel's (2015) analysis of how Vietnamese citizens rely on the language of sentiments when confronting bureaucracy. 
rented apartment among young urbanites. In many ways, our approach to public space in this special issue has echoed a growing body of research which is moving beyond "the pursuit of archetypal public space" (Qian 2020: 81) as inherited from Habermas's conception of the public sphere. Rather, the contributors have shared their embodied knowledge of "actually produced and inhabited public spaces" (ibid.), with their rhythmic patterns and modes of regulation. The contributions here remind us that spaces which are labelled as public in urban planning or everyday language are not necessarily conducive to publicness. Conversely, intimate publics may form unexpectedly, in the confines of apartment buildings or rural houses.

The liveliness of public space, as geographer Ash Amin has warned, can hardly be reduced to our concerns with "civic or political outcomes" (2015: 243). The contributors to this issue render this distinct phenomenality of public spaces. They offer accounts of the disorderliness of smells, sounds and sights; they have described sociality with its "changing character and intensity" (Amin 2015: 240) - the atmospheres of stranger encounters, the circulation of affect among bus passengers or participants in youth spaces.

Perhaps the main merit of the concept of public space lies in its capacity to call our attention to the analytical relevance of spatial disjunctions in a single locale, and to the shifts of social interactions when moving from one to another. To be on the outlook for public spaces supposes differentiating some places from others, and exploring the frames of behaviour, the materialities and subjectivities that characterise what is going on in each of them specifically. We argue that as a relational concept - a concept that induces to look for gaps and shifters in a more or less integrated system - the notion of public space is instrumental for analysing and making sense of the elusive flow of social life in a plurality of contexts.

\section{References}

Ahmed, Sara, 2000. Strange encounters: Embodied other in post-coloniality. Oxon (UK): Routledge. Amin, Ash, 2015. “Animated space,” Public Culture 27(2), pp. 239-258.

Bayly, Susan, 2020. "Beyond 'propaganda': Images and the moral citizen in late-socialist Vietnam," Modern Asian Studies 54(5), pp. 1526-1595.

Berlant, Lauren, 2008. The female complaint: The unfinished business of sentimentality in American culture. Durham, NC: Duke University Press.

Berliner, David, 2010. “Perdre l'esprit du lieu : Les politiques de l'Unesco à Luang Prabang (RDP Lao)," Terrains 55, pp. 91-105.

Butler, Judith, 1990. Gender trouble: Feminism and the subversion of identity. New York: Routledge.

Butler, Judith, 2015. Notes toward a performative theory of assembly. Cambridge, MA: Harvard University Press.

Charton, Laurence \& Julie-Anne Boudreau, 2017. “'We or them,' 'you and I,' and 'l': Spaces of intimacy and (not so) public displays of affection in Hanoi," Gender, Place and Culture A Journal of Feminist Geography 24(12), pp. 1-20. 


\section{Vanessa FRANGVILLE, Pierre PETIT \& Lisa RICHAUD}

Dai, Jinhua 戴锦华, 1999. Yinxing shuxie: 90 niandai Zhongguo wenhua yanjiu 隐形书写: 90年代 中国文化研究 (Invisible writing: Studies on Chinese culture in the 1990s). Nanjing: Jiangsu Renmin chubanshe 江苏人民出版社.

Drummond, Lisa, 2000. "Street scenes. Practices of public and private space in urban Vietnam," Urban Studies 37(12), pp. 2377-2391.

Farquhar, Judith, 2009. "The park pass," Public Culture 21(3), pp. 551-576.

Farquhar, Judith \& Qicheng Zhang, 2012. Ten thousand things: Nurturing life in contemporary Beijing. New York: Zone Books.

Florence, Eric, 2019. "Struggling around the politics of recognition: The formation of communities of interpretations and of emotions among a collective of migrant workers in twenty-first century China," in Vanessa Frangville \& Gwennaël Gaffric (eds), China's youth cultures and collective spaces, pp. 170-186. London \& New York: Routledge

Fraser, Nancy, 1990. "Rethinking the public sphere: A contribution to the critique of actually existing democracy," Social Text 25/26, pp. 56-80.

Gal, Susan, 2002. "A semiotics of the public/private distinction," Differences: A Journal of Feminist Cultural Studies 13(1), pp. 77-95.

Gaubatz, Piper, 2019. "New China square: Chinese public space in developmental, environmental and social contexts," Journal of Urban Affairs. DOI: 10.1080/07352166.2019.1619459.

Geertman, Stephanie, Danielle Labbé, Julie-Anne Boudreau \& Olivier Jacques 2016. "Youth-driven tactics of public space appropriation in Hanoi: The case of skateboarding and parkour," Pacific Affairs 89(3): pp. 591-611.

Gibert, Marie, 2014. “Repenser la notion 'espaces publics' à l'aune du contexte urbain vietnamien," Perspectives Internationales «http://perspectivesinternationales.com/? $\mathrm{p}=1162 \mathrm{\gamma}$.

Goffman, Erving, 1959. The presentation of self in everyday life. New York: Anchor.

Goffman, Erving, 1963. Behavior in public places: Notes on the social organization of gatherings. New York: The Free Press.

Graezer-Bideau, Florence, 2018. "Resistance to places of collective memories: A rapid transformation landscape in Beijing," in Italo Pardo \& Giuliana B. Prato (eds), The Palgrave handbook of urban ethnography, pp. 259-278. New York: Palgrave Macmillan.

Habermas, Jürgen, 1978 [1962]. L'espace public : archéologie de la publicité comme dimension constitutive de la société bourgeoise. Paris: Payot.

Halbwachs, Maurice, 1997 [1950]. La mémoire collective, édition critique établie par Gérard Namer. Paris: Albin Michel.

Hannerz, Ulf, 1980. Exploring the city: Inquiries toward an urban anthropology. New York \& Guildford, Surrey: Columbia University Press.

Hanoi Youth Public Spaces. 〈http://www.hanoivouthpublicspace.com〉.

Harms, Erik, 2009. "Vietnam's civilizing process and the retreat from the street: A turtle's eye view from Ho Chi Minh City," City \& Society 21(2), pp. 182-206.

High, Holly \& Pierre Petit, 2013. "Introduction: The study of the state in Laos," Asian Studies Review 37(4), pp. 417-432.

Huang, Erin, 2020. Urban horror: Neoliberal post-socialism and the limits of visibility. Durham, NC: Duke University Press. 
Public spaces in late socialist East Asia: Interactions, performativity, citizenship -Introduction

Iveson, Kurt, 2007. Publics and the city. Oxford: Blackwell Publishing.

Kendall, Paul, 2019. The sounds of social space: Branding, built environment, and leisure in urban China. Honolulu: University of Hawai'i Press.

Kim, Annette Miae, 2015. Sidewalk city: Remapping public space in Ho Chi Minh City. Chicago: University of Chicago Press.

Kurfürst, Sandra, 2012. Redefining public space in Hanoi. Places, practices and meaning. Berlin: LIT Verlag.

Lefebvre, Henri, 1991 [1974]. The production of space. Oxford: Basil Blackwell.

Lewis, J. Lowell, 2013. The anthropology of cultural performance. New York: Palgrave Macmillan.

Li, Jie, 2019. "Revolutionary echoes: Radios and loudspeakers in the Mao era," Twentieth-Century China 45(1), pp. 25-45.

Linke, Uli, 2006. "Contact zones: Rethinking the sensual life of the state," Anthropological Theory 6(2), pp. 205-225.

Lits, Marc, 2014. "L'espace public : concept fondateur de la communication," Hermès, La Revue 70(3), pp. 77-81.

Litzinger, Ralph, 2002. "Theorizing post-socialism: Reflections on the politics of marginality in contemporary China," South Atlantic Quarterly 10(1), pp. 33-55.

Lofland, Lyn, 1973. A world of strangers: Order and action in urban public space. New York: Basic Books.

Lofland, Lyn, 1998. The public realm: Exploring the city's quintessential social territory. New York: de Gruyter.

McGee, Terry, 2009. "Interrogating the production of urban space in China and Vietnam under market socialism," Asia Pacific Viewpoint 50(2), pp. 228-246.

Mitchell, Don, 1995. "The end of public space? People's Park, definitions of the public, and democracy," Annals of the Association of American Geographers 85(1), pp. 108-133.

Müller, Martin, 2019. “Goodbye, postsocialism!,” Europe-Asia Studies 71(4), pp. 533-550.

Oakes, Tim, 2019. "Happy town: Cultural governance and biopolitical urbanism in China," Environment and Planning A: Economy and Space 51(1), pp. 244-262.

Pang, Laikwan, 2006. "The collective subjectivity of Chinese intellectuals and their café culture in republican Shanghai,” Inter-Asia Cultural Studies 7(1), pp. 24-42.

Petit, Pierre, 2012. "Émergence d'un pluralisme religieux en contexte multiethnique : l'exemple du village recomposé de Thongnamy (Bolikhamxay)," in Vatthana Pholsena \& Vanina Bouté (eds), Sociétés et pouvoirs au Laos contemporain, pp. 139-161. Paris : Les Indes savantes.

Petit, Pierre, 2013. "Ethnic performance and the state in Laos. The bun greh annual festival of the Khmu," Asian Studies Review 37(4), pp. 470-490.

Qian, Junxi, 2014a. “Performing the public man: Cultures and identities in China's grassroots leisure class," City \& Community 13(1), pp. 26-48.

Qian, Junxi, 2014b. "From performance to politics? Constructing public and counterpublic in the singing of red songs," European Journal of Cultural Studies 17(5), pp. 602-628.

Qian, Junxi, 2018. Re-visioning the public in post-reform urban China: Poetics and politics in Guangzhou. Singapore: Springer. 


\section{Vanessa FRANGVILLE, Pierre PETIT \& Lisa RICHAUD}

Qian, Junxi, 2020. “Geographies of public space: Variegated publicness, variegated epistemologies," Progress in Human Geography 44(1), pp. 77-98.

Richaud, Lisa, 2016. "Au parc par temps de fête: Fêtes étatiques et performances publiques à Pékin aujourd'hui," L'Espace Politique [En ligne], 30. Lhttp://iournals.openedition.org/ espacepolitique/3949>; DOI: 10.4000/espacepolitique.3949

Richaud, Lisa, 2018. “Between 'face' and 'faceless' relationships in China's public places: Ludic encounters and activity-oriented friendships among middle-and old-aged urbanites in Beijing public parks," Urban Studies 55(3), pp. 570-588.

Richaud, Lisa, 2020. "Les plaisirs ordinaires du chant révolutionnaire en Chine post-maoïste," L'Homme 234/235, pp. 211-244.

Richaud, Lisa, 2021. "Places of 'heat and noise': Sonorous presence and the interstitial time-spaces of everyday life in contemporary Beijing," The Senses and Society 16(1), pp. 46-66.

Richaud, Lisa \& Ash Amin, 2020. "Life amidst rubble: Migrant mental health and the management of subjectivity in urban China," Public Culture 32(1), pp. 77-106.

Rovisco, Maria \& Peter Lunt, 2019. “Introduction: Performance and citizenship”, International Journal of Cultural Studies 22(5), pp. 615-629.

Salemink, Oscar, 2021. "Introduction: Heritagizing Asian cities: Space, memory, and vernacular heritage practices," International Journal of Heritage Studies 27(8), pp. 769-776.

Schwenkel, Christina, 2013. "Post/socialist affect: Ruination and reconstruction of the nation in urban Vietnam," Cultural Anthropology 28(2), pp. 252-277.

Schwenkel, Christina, 2015. "Reclaiming rights to the socialist city: Bureaucratic artefacts and the affective appeal of petitions," South East Asia Research 23(2): pp. 205-225.

Schwenkel, Christina \& Ann Marie Leshkowich, 2012. "Guest editors' introduction: How is neoliberalism good to think Vietnam? How is Vietnam good to think neoliberalism?," Positions 20(2), pp. 379-401.

Strobel, Michèle-Baj, 2017. Images du pouvoir, pouvoir des images. Culture visuelle et affiches politiques au Laos. Vientiane : Editions Dokked.

Thireau, Isabelle, 2020. Des lieux en commun. Une ethnographie des rassemblements publics en Chine. Paris: Editions de l'Ecole des hautes études en sciences sociales.

Thireau, Isabelle, 2021. "Being together at a distance, talking and avoiding talk: Making sense of the present in Victory Square, Tianjin,” The China Quarterly 246, pp. 428-446.

Thomas, Mandy \& Lisa Drummond, 2003. “Introduction,” in Lisa Drummond \& Mandy Thomas (eds), Consuming urban culture in contemporary Vietnam, pp.1-17. London \& New York: Routledge.

Tomba, Luigi, 2015. The government next door: Neighborhood politics in urban China. Ithaca \& London: Cornell University Press.

Tran, Allen, 2017. "Neurasthenia, generalized anxiety disorder, and the medicalization of worry in a Vietnamese psychiatric hospital," Medical Anthropology Quarterly 31(2), pp. 198-217.

Trnka, Susanna, Christine Dureau \& Julie Park, 2013. "Introduction: Senses and citizenships," in Susanna Trnka, Christine Dureau \& Julie Park (eds), Senses and citizenships: Embodying political life, pp. 1-32. New York: Routledge.

Vigneswaran, Darshan, Kurt Iveson \& Setha Low, 2017. "Problems, publicity and public space: A resurgent debate," Environment and Planning A 49(3), pp. 496-502. 
Public spaces in late socialist East Asia: Interactions, performativity, citizenship -Introduction

Warner, Michael, 2002. "Publics and counterpublics," Public Culture 14(1), pp. 49-90.

Wilcox, Phill, 2021. Heritage and the making of political legitimacy in Laos. The past and present of the Lao nation. Amsterdam: Amsterdam University Press.

Wu, Hung, 2005. Remaking Beijing: Tiananmen Square and the creation of a political space. Chicago: University of Chicago Press.

Yang, Jie (ed.) 2014. The political economy of affect and emotion in East Asia. Oxon: Routledge.

Yang, Jie, 2015. Unknotting the heart: Unemployment and therapeutic governance in China. Ithaca, NY: Cornell University Press.

Yang, Jie, 2016. "The politics and regulation of anger in urban China," Culture, Medicine, and Psychiatry 40, pp. 100-123.

Yang, Jie, 2017. Mental health in China: Change, tradition and therapeutic governance. Cambridge: Polity Press.

Zhang, Li, 2001. Strangers in the city: Reconfigurations of space, power, and social networks within China's floating population. Stanford, CA: Stanford University Press.

Zhang, Li, 2020. Anxious China: Inner revolution and politics of psychotherapy. Berkeley: University of California Press.

Zheng, Yongnian, 2012. "China in 2011: Anger, political consciousness, anxiety, and uncertainty," Asian Survey 52(1), pp. 28-41. 